\title{
Corporate Social Responsibility as an Ethical Imperative
}

\author{
By Angelo Nicolaides ${ }^{*}$
}

\begin{abstract}
Businesses are aware that they need to entrench CSR into their core strategic visions but many pretend to do so. When CSR is applied it should not be for solely financial returns but rather more importantly, be viewed as a moral and ethical imperative which will also add huge value and sustain competitive advantage in a world in which stakeholders are increasingly concerned about for example, environmental issues. The mounting global awareness that social responsibility is closely linked to profitability and to better business performance is changing businesses top-down. Businesses are being urged by not only their customers, but also other stakeholders, to incorporate social good and sustainability into their operating models. Businesses not embracing CSR sooner or later experience a material negative impact and lose hard earned reputations, credibility and also a strategic advantage. Businesses that are committed to CSR and embrace it are perceived to be reliable, socially responsible partners. Businesses which establish effective CSR practices obtain positive reputations, and those that are highly regarded are the ones which vigorously and incessantly embrace CSR. The importance of CSR and transparency around sustainability issues grounded on ethical practices cannot be ignored. Adopting CSR is well-acknowledged but relatively poorly implemented. It creates value and aligns businesses and society.
\end{abstract}

Keywords: Sustainability; Ethical practices; Strategy; Management practice.

\section{Methodology}

A thematic review approach was utilised in this study to describe particular areas of the literature. The purpose of the outcomes often was to identify weaknesses in CSR usage as an ethical necessity and to disseminate key steps for an improvement on the issue. An in-depth examination of principles and a narrative review was conducted to summarise different primary studies from which conclusions were drawn into a holistic interpretation contributed by my own experience, existing theories and models on CSR and ethics in business practice. The strength of this methodology is that it allowed me to comprehend the diversities and pluralities of understanding around scholarly research on the topics and it afforded me the opportunity to speak with self-knowledge, reflective practice and acknowledgement of shared educational phenomena. The focuses was thus on a central element which was taken under consideration from different point of views and sought to discover needed approaches, to CSR application in business, providing a range of different inputs.

*Professor, Graduate School of Business Leadership, University of South Africa, Pretoria, South Africa. Email: nicola@unisa.ac.za. 


\section{Introduction and definition of CSR}

The concepts Corporate Social Responsibility (CSR) and Business Ethics have distinct identities. However, they are often used interchangeably. The term business ethics is intended as "a combination of two very familiar words, namely business and ethics" $" 2$ but there are unfortunately businesses that are not ethical in their CSR initiatives. Genuine CSR implies businesses fully embrace environmental and societal challenges. The notion of CSR is not new but it is progressively becoming a decisive part of business practices globally. Adam Smith's 1776 An Inquiry into the Nature and Causes of the Wealth of Nations, stated that the free market didn't continuously perform flawlessly ${ }^{3} \mathrm{He}$ thus counselled that marketplace participants must act honestly and rightly toward one other if the ideals of the free market are to be at all attained. ${ }^{4}$ There have been numerous proponents and definitions of CSR since the 1960s which have all ultimately led to the fine-tuned contemporary definitions. Nonetheless, Van Marrewijk ${ }^{5}$ states that the many and varied definitions of CSR are usually biased toward specific interests and this hinders the development and universal implementations of the concept. Only a few are touched on here to demonstrate the evolutionary process involved. The definitions today are multidisciplinary and the consequence of an assortment of themes including inter alia business ethics, corporate governance, social responsibility, sustainable development, the triplebottom line, corporate philanthropy and corporate citizenship,

In 1960 the Iron Law of Responsibility, maintained that the social responsibility of businessmen needed to be proportionate to their social influence'. ${ }^{6}$ There was a belief that businessmen ought to manage their enterprises in a capitalistic economic system that satisfies the expectations of the community in general. ${ }^{7}$

In the 1970s it was generally accepted that a socially responsible business was one in which managerial staff balanced an array of interests. Not only profit was pursued but also to a limited extent the interest of employees, suppliers, dealers and local communities - thus social programs were utilised to enhance profits ${ }^{8}$. Business also had economic, legal, ethical, and optional expectations of society to attend to. ${ }^{9}$

Carroll ${ }^{10}$ set the path for the current tone and stated that CSR encompasses the conduct of a business that makes it economically lucrative, ethical, law abiding, and caring socially. CSR is thus, founded on a pyramid of economic, legal, ethical and voluntary or philanthropic aspects.

\footnotetext{
${ }^{2}$ Dimitriades (2007).

${ }^{3}$ Sutherland (2008).

${ }^{4}$ Binder (2015).

${ }^{5}$ Van Marrewijk (2003).

${ }^{6}$ Davis (1960).

${ }^{7}$ Frederick (1960).

${ }^{8}$ Johnson (1971); Eells \& Walton (1974).

${ }^{9}$ Carroll (1979).

${ }^{10}$ Carroll (1983).
} 
Reder $^{11}$ and then Hopkins ${ }^{12}$ both held all-inclusive conceptions of CSR denoting the manner in which business conducts its internal operations and deals with the employees, and whether it treats its stakeholders ethically or in any particular socially responsible manner.

Pinney ${ }^{13}$ viewed CSR as part of a set of management practices that safeguard that a company curtails the negative impacts of its actions on society while seeking to make best use of any positive impacts. CSR is thus voluntarily contribution to a better society and a drive towards a pristine natural environment. By way of contrast, Marsden ${ }^{14}$ and also Baker ${ }^{15}$ asserted that CSR is about the non-negotiable behaviour of companies and their responsibility to society relating to their operations when it comes to the environmental, social and economic impacts which need to be positive. McWilliams and Siegel ${ }^{16}$ and then Lea ${ }^{17}$, called on companies to go beyond mere adherence to the law and morally seek to do social good as part of concern for both social and environmental issues.

The success of any company was also measured by its involvement in societal issues $^{18}$ and tangible and measurable outcomes should be in place relating to the economic worth of a company. Matten and Moon ${ }^{19}$ posit that CSR reflects the social necessities and social consequences of business achievement. These comprise of expressed and communicated policies and practices of businesses that reflect business accountability for enacting societal good. Carroll and Buchholtz ${ }^{20}$ state that CSR incorporates the economic, legal, ethical and philanthropic expectations placed on organizations by society.

When we view CSR through Freeman's lens of normative stakeholder theory, it is evident that CSR is a subcategory of business ethics. Freeman ${ }^{21}$ states that stakeholder theory begins with the supposition that values are unavoidably and explicitly a part of business conduct. The concept of CSR has been linked to sustainable development and has come to integrate three dimensions including an economic dimension in which profits are important, a social dimension in which responsibility to society and all stakeholders is vital and an environmental dimension in which responsibility for the natural environment is essential. The importance of Corporate Social Responsibility (CSR) cannot be underestimated as it has a huge influence on public perceptions of a business. ${ }^{22}$

CSR is thus, increasingly viewed as a vital strategic tool for corporations and smaller enterprises. Within this context, stakeholders of businesses progressively want to know more about what such entities are doing in the area of CSR and how

\footnotetext{
${ }^{11}$ Reder (1994).

${ }^{12}$ Hopkins (1998).

${ }^{13}$ Pinney (2001).

${ }^{14}$ Marsden (2001).

${ }^{15}$ Baker (2003).

${ }^{16}$ McWilliams \& Siegel (2001).

${ }^{17}$ Lea (2002).

${ }^{18}$ Novethic (2003); Saunders (2006); Ahearne, Bhattacharya \& Gruen (2010).

${ }^{19}$ Matten \& Moon (2004).

${ }^{20}$ Carroll \& Buchholtz (2015).

${ }^{21}$ Freeman (2004) cited in Parmar, Freeman, Harrison, Wicks, Purnell \& Colle (2010).

${ }^{22}$ Zyglidopoulos (2002).
} 
they are morally driven to operate and they thus seek more transparency and accountability from businesses. ${ }^{23}$ On a daily basis, the media feature articles describing fraud, corruption and other criminal activities stemming from business practices. Countless company scandals smear the image of businesses. Since stories such as that of the Italian dairy business Parmalat, whose directors defrauded investors of billions of US dollars, and many other such reports, it has become immutable for business to win stakeholder trust and respect. ${ }^{24}$ This has been shown to have transformed corporate governance and management in recent times. ${ }^{25}$ Kotler and Lee ${ }^{26}$ state that most companies now include CSR in their communications information related to ethical values and responsible behaviour, in the hope of improving a brand's reputation and in order to gain public recognition.

There are of course those who see no need for CSR at all. Milton Friedman ${ }^{27}$ argued that all that matters is the bottom line and that CSR is generally undertaken based on narcissistic and egotistical motives rather than out of a genuine care for society. The maximisation of profits is all that matters. In many businesses CSR is nothing more that "the belief that a firm has ulterior motives based on contextual information." ${ }^{28}$ Despite the above sentiments, it is evident that stakeholders are more than ever expecting businesses to recognise their social responsibilities. They expect them to make positive contributions within the communities in which they operate and to thus inform society of the scope and effectiveness of their CSR endeavours. ${ }^{29}$ Businesses can no longer afford to ignore calls for real CSR initiatives and are pressurised by society to engage in activities beyond the mere bottom-line and for example, to be especially cognisant of the need to care for the fragile global environmental. Their CSR must additionally embrace the welfare of employees and above all promote ethical business conduct. A Stakeholder Theory perspective on the ethicality of CSR initiatives suggests that managers should recognise and attend to the welfare of a broader set of constituent groups including employees. ${ }^{30}$ Normative stakeholder theory in CSR draws its philosophy from Ethics, and it upholds the notion that businesses are morally accountable to look after the concerns of all their stakeholders which include owners, employees, customers, agents, vendors and the community rather than only the shareholders who are the owners of the business. ${ }^{31}$

Adam Smith, in one of his major works, The Theory of Moral Sentiment, asserts that one cannot purport to be human without having at least some sense of what it means to be moral. ${ }^{32}$ Thus the notion of CSR) comes into mind. Numerous businesses are adopting plainly articulated CSR policies and making these an

\footnotetext{
${ }^{23}$ de Grosbois (2012) at 897.

${ }^{24}$ Delaney (2004).

${ }^{25}$ Carroll \& Shabana (2010).

${ }^{26}$ Kotler \& Lee (2008).

${ }^{27}$ Friedman (1970).

${ }^{28}$ Yoon, Gürhan-Canli \& Schwarz (2006).

${ }^{29} \mathrm{de}$ Grosbois (2012) at 896.

${ }^{30}$ Aguinis (2011).

${ }^{31}$ Rodin (2005).

${ }^{32}$ Young (2001).
} 
integral part of their strategy as well as key focal points of business ethos and culture.

Where businesses are perceptibly socially responsible they are likely to obtain more customers or at least more satisfied customers. They will also potentially tend to attract like-minded employees, who are intent on driving global sustainability and become more independent of governmental handouts and they invariably make their business stable and sustainable. ${ }^{33}$ Many businesses are hypocritical when it comes to CSR and they claim to do something worthwhile when in reality they are not and merely upholding a façade. ${ }^{34}$ Generally, consumers do not believe the claims of business that they are engaging in true CSR activities, but rather see a plethora of profit-based motivations in most business CSR endeavours and believe that business does not truly embrace CSR. Consequently, some businesses are concentrating on effective CSR due to the great pressure exerted on them by especially the public.

In 2015, the notion of sustainable development gathered momentum as was evidenced by the third annual conference on Financing for Development of the U.N.'s Department of Economic and Social Affairs in Addis Ababa, Ethiopia, the U.N. Sustainable Development Summit in New York and finally, the sixth annual Paris Climate Conference. Each of these stressed the importance of CSR. ${ }^{35}$

\section{The Role of Business in Society}

Especially big business plays a pivotal role in society and shapes government policy and therefore is challenged to conduct itself in a manner that contributes positively to the meaningful socio-economic transformation of society and the protection of the environment. However all business irrespective of size have a role to play in CSR initiatives. The common hierarchical and bureaucratic organizational structures which are found in most businesses are inherently ineffective and take little cognizance of the human element, which is in essence the lifeblood of the business. Management, and particularly in the upper echelons of an organization, maintains the power to deliberate and formulate decisions which ultimately impact on subordinates and all other stakeholders and it is they who should be the custodians and promoters of CSR. Business leaders clearly play a huge role in whether or not their business operates ethically and is CSR sensitive or not. In Socrates Republic, the "Guardians" are leaders who view their high office in terms of their social responsibility. It is incumbent upon them to serve society by promoting ethical practice. ${ }^{36}$

Aristotle suggests in his Nicomachean Ethics that morality is not simply learned by reading about it, but by witnessing the behaviour of a morally sensitive person who serves as a role-model. From a philosophical perspective, rolemodelling is not enough to satisfy the basic needs of an ethical business at either

\footnotetext{
${ }^{33}$ Davies (2003).

${ }^{34}$ Wagner, Lutz \& Weitz (2009).

${ }^{35}$ Myers (2016).

${ }^{36}$ Gini (1997).
} 
the normative or descriptive levels. Jean-Paul Sartre states that we are by definition morally bound because we share the planet with others whom we need to consider in the choices we make. ${ }^{37}$ The primary paradigm of evaluation is always the self in relation to others. We should be basically always acting on the behalf of the interests of others ${ }^{38}$ but sadly do not. The expectations of customers are thus not met. The public expects businesses to operate in the best interests of society all the time. ${ }^{39}$ In this regard, CSR communications to stakeholders commonly enjoy superior credibility when they come from sources not controlled by a business. ${ }^{40}$

What is needed is sound business ethics, CSR policies that work and good governance. Ethics, by its character, is part of the discretionary behaviour of individuals and groups and deals with a hierarchy of values and how individuals and groups may comply with them. The values of businesses must be passed on to all employees, if ethical business conduct is to prevail. Employees need to know the consequences of unethical conduct. According to More and Webley, ${ }^{41}$ there is a gap between the existence of company ethics and CSR policies and the embedding of its ideas and values into the 'blood stream' of an organization. The Enron debacle demonstrated clearly that ethical misdemeanours soon become cataclysmic events which can bring a major business to its knees if not checked. ${ }^{42}$

A business that behaves ethically is differentiated from others by the public at large and is able to gain a strategic competitive advantage in the marketplace by not only communicating its values to its stakeholders but also by its actual behaviour. Good governance and a strong anti-corruption stance are part and parcel of CSR. Accountability and transparency must be articulated in the vision of a business and CSR can only take root in a business if management is able to develop a meaningful concept of what CSR means in its own organisation.

Employees must be key stakeholders in CSR initiatives since they are able to serve as agents for needed social transformation when they pressure their employers to adopt socially responsible behaviour. ${ }^{43}$ In any event, employee buyin is critical when seeking to ensure operative CSR programmes and effective policies. $^{44}$

CSR thus needs to be embraced at senior management levels and be a fundamental component of a strategic plan of a business. It needs to permeate through a business throughout all the employee echelons. Both leaders and employees must be accountable and responsible for their behaviour in the workplace. Each of them is driven by their own internal sets of values. That is why a common set of values must be embedded in employees and introduced via comprehensive programmes and documentation such as a Code of Conduct and a Code of Ethics, and these have strong links with CSR. The Codes need to be

\footnotetext{
${ }^{37}$ Sartre (1960).

${ }^{38}$ Gini (1996).

${ }^{39}$ McElhaney (2009).

${ }^{40}$ Skard \& Thorbjørnsen (2014).

${ }^{41}$ Webley (2003).

${ }^{42}$ Salter (2004)

${ }^{43}$ Aguilera, Ruth, Rupp, Williams \& Ganapathy (2007).

${ }^{44}$ Ramus \& Steger (2000).
} 
written and intelligible if management hopes to have employee compliance. Furthermore it may be necessary that certain departments have slightly different aspects to focus on. ${ }^{45}$ There are differences between a Code of Conduct and a Code of Ethics, and yet both guide appropriate CSR initiatives and actions. Codes of Conduct tend to address the values of a business and how those values reflect the values of society and often contain appropriate actions and behaviour. They are generally linked to the mission of a business. Codes of Ethics, on the other hand, are generally more global statements about operational values and beliefs that define a business. ${ }^{46}$ When consumers, employees and other stakeholders receive negative information relating to a business's operations and its neglect of CSR, this is highly problematic. ${ }^{47}$

\section{How does a Company Implement CSR and Articulate its Values so that its Stakeholders are Confident beyond the Bottom Line?}

A challenge for business is to understand how CSR is socially constructed in a specific milieu and how to take this ultimately considered when business strategies are developed. In order assist this social construction, businesses now generally assume social corporate reporting to advance their social performance and to ensure that they becoming sustainable. Social corporate reporting also delivers actions as to how an organisation lives up to the shared values it espouses and has committed itself to ${ }^{48}$ as the obligation to CSR is rising internationally, directors of companies are forced to, recognise their responsibilities to society. They are forced to carefully consider the consequences of business decisions that they take. Armstrong ${ }^{49}$ asserts that business CSR activities should emphasise community, environment, market place, and also the work place by integrating social features into products and manufacturing processes. Furthermore, they should adopt reformist human resource management practices which consider human consciousness and what it means to be human. Such aspects will for example, support the attaining of desirable higher levels of environmental performance.

The notion of social justice and hence the dawning of an elevated consciousness of socially responsible actions ${ }^{50}$ obliges businesses to have a strategic vision of CSR and its myriad of implications. Consumers are far more aware of and thus more demanding when it comes to environmental protection issues and are increasingly purchasing from companies that are established socially responsible entities that are concerned about the environment. CSR is thus a strategic advantage for businesses when honestly affected. ${ }^{51} \mathrm{CSR}$ involvement at meaningful levels has an influence on business as demonstrated in a survey which

\footnotetext{
${ }^{45}$ Lovitsky \& Ahern (1999).

${ }^{46}$ Brandl \& Maguire (2002).

${ }^{47}$ Lichtenstein, Drumwright \& Braig (2004).

${ }^{48}$ Hess (2008).

${ }^{49}$ Armstrong (2009).

${ }^{50}$ Bergtedt \& Nilsson (2010).

${ }^{51}$ D’Souza, Taghian, Lamb \& Peretiatko (2007); Hopkins, Roche \& Hopkins (2008).
} 
exposed that $85 \%$ of Americans have a greater positive image of a brand when it is connected to a cause they also relate to. ${ }^{52}$

The Caux Initiatives for Business promote CSR through dialogue between all the relevant stakeholders of a business ${ }^{53}$ and CSR is the right thing to do and should be ingrained into the operational DNA of a business so that it shows true commitment to its employees and other stakeholders in society and especially local communities. Businesses need to manage the expectations of their stakeholders in a fully accountable and transparent manner. This means that CSR reports must be authentic. Failure to be honest in reporting is unacceptable and taints the credibility of a business, posing huge problems for risk management. Verifiable corporate social performance (CSP) is important as it demonstrates the social performance outcomes of a business's responsibility for CSR ${ }^{54}$ In this context even philanthropy is helpful. Porter and Kramer ${ }^{55}$ state that philanthropy can often be the most cost-effective way for a company to advance its competitive situation, permitting companies to leverage the efforts and infrastructure of nonprofits and other institutions. Operative CSR must be grounded on ethical values that have actually been integrated into a business and which are clearly expressed in all interactions with the public at large. ${ }^{56}$

Unfortunately, and to their ultimate detriment, many businesses are insincere about information that they put into the public arena concerning their CSR activities. For many businesses CSR endeavours are merely undertaken or said to be undertaken in what is a facade, for self-centred reasons ${ }^{57}$ and they are ultimately found out. Thus the more transparent a business is the better it will function in disseminating information that is true, and it will gain a competitive advantage and increased shareholder value.

Studies on the issue of CSR communication ${ }^{58}$ show that messages to stakeholders require good fit to enhance their credibility and efficacy. Where there is a good fit between public's expectations and the relations of a business and also the CSR actions of the business then the public is likely to perceive the CSR initiative as compatible and dependable when viewed as part of a business's central operations. There is invariably less scepticism and greater trust in the CSR message.

Sierra-García, Zorio-Grima and García-Benau ${ }^{59}$ note that in recent years numerous studies have described an upsurge in the disclosure of voluntary CSR reports together with solid evidence that the reports have been submitted for external assurance and auditing. This has served the credibility of many businesses well and enhanced their reputations. A triple-bottom-line approach is however needed in which the planet, people and then profits are pursued followed by social corporate reporting which meets and exceeds societal expectations. Effective

\footnotetext{
${ }^{52}$ Cone Inc. (2008).

${ }^{53}$ Cassel (2001).

${ }^{54}$ Ioannou \& Serafeim (2012).

${ }^{55}$ Porter \& Kramer (2002).

${ }^{56}$ Villagra \& López (2013).

${ }^{57}$ Hess \& Warren (2008).

${ }^{58}$ Elving (2013); Du, Bhattacharya \& Sen (2010).

${ }^{59}$ Sierra-García, Zorio-Grima \& García-Benau (2015).
} 
reporting will serve to confirm that a business is working towards becoming truly sustainable. Authentic social corporate reporting also supports a business to determine how well it is living up to the shared values it has committed itself to indorse. $^{60}$

\section{Business Responses}

At the outset, it is important to state that top management in any business need to commit to CSR and to integrate it as part of a business stratagem. While some businesses are sceptical about CSR and how it grows profits and performance, the majority are however cognisant of the value CSR brings in a win-win scenario and it has become a strategic imperative. Consumers are more and more demanding in their calls for business accountability and would rather conduct business with companies that recognise that synergising social responsibility initiatives with their operational model can benefit them in shaping a sustainable competitive advantage in the marketplace. Social corporate reporting is critical as it is about accountability and sustainability issues, and it is also important since it seats society at the core of the scrutiny and queries the legitimacy of an organisation's actions, and to an extent it's very right to exist. ${ }^{61} \mathrm{~A}$ study Becker-Olsen et al. ${ }^{62}$ confirmed that stakeholders attitudes towards a business was more positively valued, based on the fit between organization and societal causes as well as the principal motivation of increasing the profit of a business. The primary motivation was correlated to the perceived genuineness of a company's CSR activities by using CSR as a means to achieve another goal rather than a purely philanthropically one in nature.

The 2015 Nielsen Global Corporate Sustainability Report found that 66 percent of consumers were prepared to pay more for environmentally sustainable brands, for example, up from 55 percent in 2014 and 50 percent in $2013 .{ }^{63}$ This demonstrates that consumers have espoused more sustainable behaviours while a number are either working for or supporting organizations devoted to social and environmental change. Companies and their executives are noticing such tendencies. Ever more potential millennial employees are looking at a company's CSR and sustainability impact decisions before deciding where to seek employment or where to invest.

A 2015 Cone Communications/Ebiquity Global CSR Study found that $91 \%$ of global consumers expect companies to do more than merely make a profit, but also operate responsibly to address social and environmental issues plaguing the planet and $84 \%$ say they seek out responsible products where possible. Many (90\%) said that they would shun a company if they learned of irresponsible or misleading business practices. ${ }^{64}$

\footnotetext{
${ }^{60}$ Hess (2008).

${ }^{61}$ Gray (2001).

${ }^{62}$ Becker-Olsen, Cudmore \& Hill (2006).

${ }^{63}$ The Nielsen Company (2015).

${ }^{64}$ Cone Inc. (2015).
} 
Not only large business but also smaller businesses need to embrace CSR. Many small businesses are also dedicated to environmental protection and the implementation of sustainable practices. Putting CSR into practice can be a daunting task. It requires not only business within legal boundaries, but also within ethical boundaries. Furthermore, it requires leaders who are willing to adhere to very high moral standards. Senior management need to be role models for the rest of the employees and make sure that regular training concerning CSR takes place. ${ }^{65}$ It is a dynamic process in which employees in a business actively engage with each other to uncover what it is precisely that CSR means. The buy-in of employees is important and they need to stand behind their senior manager's goals and strategic vision for the business.

In South Africa, for example, there is a basic ethics infrastructure in most businesses, but they are not well-formulated and thought out and thus are ineffective. In certain cases, while there are Codes for appropriate behaviour, there is only 'lip service' to CSR and no tangible commitment to ethics management on the part of senior management. ${ }^{66}$ It is ultimately the top executives' actions which define a company's culture. If the employees do not trust them absolutely, chaos will prevail. Clearly, the business will take its cues from society and the prevailing attitude towards CSR in the context of global societal realities. Wagner et al. ${ }^{67}$ posit that there is often a perceived inconsistency in the information from businesses that is received by the customers concerning CSR initiatives and this nothing more than corporate hypocrisy as such entities claim to be doing something that they are not

For many employees CSR is a new aspect in the workplace that they try to relate to in terms of past-experience. They try to make sense of it and new meaning is created ${ }^{68}$ as when CSR is introduced to them in the workplace. If they do not see CSR as important, they may become victims of conflict of interest and become easy to sway in unethically compromising situations, to the detriment of both society and the business they serve. The business must provide an environment that builds society and is conducive to employee development and self-actualisation. Senior managers who fail to engage in an investigation of their ethical actions will ultimately fail in their endeavours. CSR is after all, the 'right thing' to do. The business strategies of companies adopting CSR initiatives tend to focus on employees, the environment, accountability, transparency and basically good governance. If the community is aware of a business being CSR sensitive, its brand and image reputation is enhanced leading to greater sales and repeat business. This is ideal for the much sought after increased bottom-line. Customers begin to see the differences, advantages and benefits of dealing with that company while employees tend to be more loyal to companies that value them as individuals and which consider human rights to be important. Purely on a human rights basis, CSR is desirable and necessary. The reputation of a business is far more important than expediency.

\footnotetext{
${ }^{65}$ Niedermeier \& Rhodes (2002).

${ }^{66}$ Malan (2002).

${ }^{67}$ Wagner, Lutz \& Weitz (2009).

${ }^{68}$ Weerd (2001).
} 
While investors desire a good return for their money, they are increasingly demonstrating that CSR is a very important aspect to consider in a business when selecting an investment option. Responsibility towards society is essential on the part of a business, irrespective of how big or small it may be. While government control and regulation is also vital, businesses have an ever-greater role to fulfil in setting a correct moral course no matter how turbulent economic times may become. Employees need to know that they have support when their ethics are challenged in the workplace. Customers and suppliers also need to be aware that they are under CSR scrutiny on the part of the business they deal with. All companies are responsible for holding the rest of the business community accountable for unethical business practice, whether in CSR or corporate compliance, or environmental or social responsibilities.

\section{Conclusions}

Businesses should make their corporate values known via their Codes of Conduct. These values should clearly spell out the goals and vision of the business and should be in the public domain. There should be an unambiguous commitment to all stakeholders concerning business conduct and the setting of minimum standards, the community at large and the workplace. The CSR policy should then also include, from the Code of Ethics and Code of Conduct, a set of principles dealing with ethical corporate governance, quality assurance, environmental sustainability, acceptable standards and conduct, a social impact assessment and how local communities can be supported. All stakeholders should be engaged for their input in the CSR policy and the Code of Conduct must be written as a policy statement, accessible and relevant. There needs to be training on a Code of Conduct incorporating CSR and it should be reviewed during training and during new employee orientation. ${ }^{69}$ The way in which CSR is driven and implemented can be beneficial if it is performed well and rather disastrous poorly conducted. Well-executed CSR can attract financiers interested in socially responsible investing as well as craft a strategic competitive advantage. CSR application creates shared value between employees and a business and has a positive impact on productivity.

It is the task of management to ensure that the CSR principles of the company are upheld throughout the business. To this end, all employees must receive an intelligible written copy of the code of conduct, receive training on corporate values and their compliance with the code monitored. The code should not be 'cast in iron' but regularly reviewed. A range of diversity issues including sexual orientation, religion, ethnicity and gender could also be included in the CSR policy. Generally, it is the directors of companies who should be legally accountable for the actions of their companies. This is not to suggest that governments should not enforce corporate governance and accounting rules more. Stock exchanges could assist by collecting information on the ethical and environmental performances of listed companies and make their findings known

\footnotetext{
${ }^{69}$ Brandl \& Maguire (2002).
} 
to the public. A key characteristic of effective CSR is communicating honestly to stakeholders and this ultimately benefits a company's brand and reputation as it gives prominence to social engagement activities.

Recent scandals in various industries clearly show that customers will happily pay more for products and services from companies that demonstrate socially and ethically responsible business conduct. This includes quality service provision, honest dealings with all stakeholders and environmental sensitivity. Companies that opt to have strong CSR policies and effective codes of conduct will have a competitive edge over those which do not. There needs to a balance between commercial responsibility and social responsibility. Only in this way can a business sustain itself in the long-term. A business needs to ensure that its CSR activities are adequately allied with standard business operations that the stakeholders will perceive it to be capable in its activities.

However, the paramount need is Businesses which tend to avoid CSR issues, do so at their own peril and will ultimately lose momentum and fail to sustain themselves. Individual customers could also influence businesses to be more CSR conscious by factoring in business ethics and CSR initiatives into their purchases from companies. CSR should be an essential aspect of business, as it is the right thing to do and does ultimately pay off in many and varied ways. It is apparent that the future of a business will be determined by the real value that it provides to all stakeholders in their immediate community and in society in general.

\section{References}

Aguilera, R., Ruth,V., Rupp, D., Williams, C. \& J. Ganapathi (2007). 'Putting the S back in corporate social responsibility: A multi-level theory of social change in organizations' in Academy of Management Review 32(3):836-863.

Ahearne, M., Bhattacharya, C.B. \& T. Gruen (2010). 'Antecedents and consequences of customer - company identification: Expanding the role of relationship marketing' in Journal of Applied Psychology 90(3):574-585.

Aguinis, H. (2011). 'Organizational responsibility: Doing good and doing well' in Zedeck, S. (Ed.). APA handbook of industrial and organizational psychology. Washington, DC: American Psychological Association, Vol.3, 855-879.

Armstrong, M. (2009). Armstrong's Handbook of Human resource Management Practice. 11th ed., London: Kogan Page

Baker, J. (2001). International Confederation of Free Trade Unions, to Organisation for Economic Co-operation and Development. Paper presented at the Conference on Corporate Social Responsibilities, Paris, France.

Becker-Olsen, K.L., Cudmore, B.A. \& R.P. Hill (2006). 'The impact of perceived corporate social responsibility on consumer behaviour' in Journal of Business Research, 59(1):46-53.

Bergtedt, A. \& J. Nilsson (2010). What's your story?: Stories' effect on corporate image. Retrieved from http://www.essays.se/essay/d6ea4f15da/

Binder, A. (2015). CSR and Sustainability: The New Strategic Imperatives, RF Binder on the Holmes Report. Retrieved from https://www.holmesreport.com/agencyplaybook/ sponsored/article/csr-and-sustainability-the- new-strategic-imperatives 
Brandl, P. \& M. Maguire (2002). 'Codes of ethics: A primer on their purpose, development and use' in The Journal for Quality and Participation 25(4), AQP, Cincinnati.

Carroll, A.B. (1979). 'A three dimensional conceptual model of social responsibility performance' in Academy of Management Review 4(4):497- 505.

Carroll, A.B. (1983). 'Corporate social responsibility: Will industry respond to cutbacks in social program funding' in Vital Speeches of the Day 49(19): 604-608.

Carroll, A.B. \& A.K. Buchholtz (2015). Business and Society: Ethics, Sustainability, and Stakeholder Management. 9th ed. Stamford: Cengage Learning.

Carroll, A.B. \& K.M. Shabana (2010). 'The business case for corporate social responsibility: A review of concepts, research and practice; in International Journal of Management Reviews 12(1): 85-105.

Cassel, D. (2001). 'Human Rights and Business Responsibilities in the Global Marketplace' in Business Ethics Quarterly 11(2): 261-274.

Cone Inc. (2008). Cone Social Responsibility Study 2008. Mahwah, NJ, Lawrence Erlbaum Associates Retrieved from http://www.coneinc.com/stuff/contentmgr/files/ 0/8ac1ce2f758c08eb226580a3b67d5617/files/cone25thcause.pdf.

Cone Inc. (2015). Cone Communications/Ebiquity Global CSR Study. Retrieved from http://www.conecomm.com/research-blog/2015-cone-communications-ebiquityglobal-csr-study

Davies, R. (2003). 'The business community: Social responsibility and corporate values' in J.H. Dunning (Ed.). Making globalization good: The moral challenges of global capitalism. New York: Oxford University Press, pp. 301-319.

Davis, K. (1960). 'Can business afford to ignore social responsibility' in California Management Review 2:70-75.

de Grosbois, D. (2012). 'Corporate social responsibility reporting by the global hotel industry: commitment, initiatives and performance' in. International Journal of Hospitality Management 31:896 - 905.

D’Souza, C., Taghian, M., Lamb, P. \& R. Peretiatko (2007). 'Green decisions: Demographics and consumer understanding of environmental labels' in International Journal of Consumer Studies 31(4):371-376.

Delaney, S. (2004). 'Parmalat Spurs Call for Reform in Business-Italian Government Plans to Strengthen Oversight' in Washington Post, January 20, 2004.

Dimitriades, Z.S. (2007). 'Business Ethics and Corporate Social Responsibility in the eEconomy: A Commentary' in Electronic Journal of Business Ethics and Organisation Studies 12 (2).

Du, S., Bhattacharya, C.B. \& S. Sen (2010). 'Maximizing business returns to corporate social responsibility (CSR): The role of CSR communication' in International Journal of Management Reviews 12(1):8-19.

Elving, W.J.L. (2013). 'Scepticism and corporate social responsibility communications: the influence of fit and reputation' in Journal of Marketing Communications 19(4):277-292.

Eells, R. \& C. Walton (1974). Conceptual foundation of business. 3rd Ed., Burr Ridge, IL: Irwin.

Frederick, W.C. (1960). 'The growing concern over business responsibility' in California Management Review 2(4):54-61.

Friedman, M. (1970). 'The Social Responsibility of Business Is to Increase Its Profits' in The New York Times Magazine, September 13, 1970.

Gray, R. (2001). 'Thirty years of social accounting, reporting and auditing: what (if anything) have we learnt?' in Business Ethics: A European Review 10(1):9-15. 
Gini, A. (1996). Ethics \& Leadership, Academy of Leadership, Kellogg Leadership Studies Project Working Paper.

Hess, D. (2008). 'The three pillars of corporate social reporting as new government regulation: disclosure, dialogue and development' in. Business Ethics Quarterly 18(4):447-482.

Hess, D. \& D.E. Warren (2008). The Meaning and Meaningfulness of Corporate Social Initiatives. London: J. Wiley and Sons.

Hopkins, M. (1998). The planetary bargain: Corporate social responsibility comes of age. London: Macmillan.

Hopkins, M., Roche, J. \& I. Hopkins (2008). 'Turbulent times: CRS Now needed more than ever before'. Retrieved from http://mhcinternational.com/monthly-features/ articles/95-csr-in-turbulent-times.

Ioannou, I. \& G. Serafeim (2012). 'What drives corporate social performance?: the role of national-level institutions' in Journal of International Business Studies 43:834 - 864.

Johnson, H.L. (1971). Business in contemporary society: Framework and issues. Belmont, CA: Wadsworth.

Kotler, P. \& N. Lee (2008). Social marketing: Influencing behaviors for good. Los Angeles: Sage Publications.

Lea, R. (2002). Corporate social responsibility, Institute of Directors Member Opinion Survey. London: IOD.

Lichtenstein, D.R., Drumwright, M.E. \& B.M. Braig (2004). 'The Effect of Corporate Social Responsibility on Customer Donations to Corporate-Supported Non-profits' in Journal of Marketing 68 (4):16-32.

Lovitzky, J.A. \& J. Ahern (1999). 'Designing compliance programs that foster ethical behaviour' in Healthcare Financial Management 53(3), HFMA, Illinois.

Malan, D. (2002). 'Applying tick-box ethics' in Accountancy SA, SAICA, Johannesburg

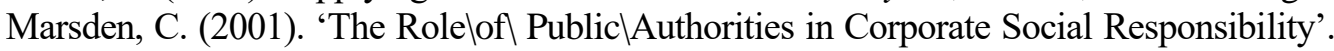
Retrieved from http://www.alter.be/socialresponsibility/people/marchri/en/display Person

Matten, D. \& J. Moon (2004). "Corporate social responsibility education in Europe" in Journal of Business Ethics 54:323-337.

McElhaney, K. (2009). 'A strategic approach to corporate social responsibility' in Leader to Leader 52(1):30-36.

McWilliams, A. \& D. Siegel (2001). Corporate social responsibility: A theory of the firm perspective' in Academy of Management Review 26(1):117-127.

More, E. \& S. Webley (2003). Does Business Ethics Pay? Institute of Business Ethics, London.

Myers, R. (2016). Social Responsibility: The New Corporate Imperative, Institutional Investor, September 19, 2016. Retrieved from https://www.institutionalinvestor.com/ article/b14z9n6xlbqcvk/social-responsibility-the-new-corporate-imperative

Niedermeier, S. \& L. Rhodes (2002). 'Creating a culture of credibility' in The Journal for Quality and Participation 25(4), AQP, Cincinnati.

Parmar, B.L., Freeman, R,E., Harrison, J.S., Wicks, A.C., Purnell, L. \& S. Colle (2010). 'Stakeholder Theory: The State of the Art' in The Academy of Management Annals 4(1):403-445.

Pinney, C. (2001). 'Imagine Speaks Out. How to Manage Corporate Social Responsibility and Reputation in a Global Marketplace: the Challenge for Canadian Business'. Retrieved from http://www.imagine.ca/content/media/teamcanada.china.paper.asp? section= media.

Porter, M.E. \& M. R. Kramer (2002). 'The Competitive Advantage of Corporate Philanthropy' in Harvard Business Review 80(12):56-69. 
Ramus, C.A. \& U. Steger (2000). 'Roles of supervisory support behaviours and environmental policy in employee eco initiatives at leading edge European companies' in Academy of Management Journal 43(4):605-626

Reder, A. (1994). In pursuit of principle and profit: Business success through social responsibility. New York: Putnam.

Rodin, D. (2005). What's wrong with business ethics. UNESCO. Oxford: Blackwell Publishing.

Salter, M. (2004). 'Innovation Corrupted: The Rise and Fall of Enron' in Harvard Business School Case 9, 904-936.

Sartre, J.P. (1960). Existentialism and Human Emotions. New York: The Wisdom Library.

Saunders, R. (2006). CSR: How to get an ethical advantage. Retrieved from http://www. highbeam.com/doc/1G1-156029766.html

Sierra-García, L., Zorio-Grima, A. \& M. García-Benau (2015). 'Stakeholder engagement, corporate social responsibility and integrated reporting: an exploratory study' in Corporate Social Responsibility and Environmental Management 22: 286 - 304.

Skard, S. \& H. Thorbjørnsen (2014). 'Is publicity always better than advertising? The role of brand reputation in communicating corporate social responsibility' in Journal of Business Ethics 124(1): 149-160.

Sutherland, K. (Ed.) (2008). An Inquiry into the Nature and Causes of the Wealth of Nations: A Selected Edition Adam Smith (Author), Oxford, UK: Oxford Paperbacks.

The Nielsen Company (2015). The Sustainability Imperative: New Insights on Consumer Expectations. Retrieved from https://www.nielsen.com/content/dam/nielsenglobal/ dk/docs/global-sustainability-report-oct-2015.pdf

Van Marrewijk, M. (2003). 'Concepts and definitions of CSR and corporate sustainability: between agency and communion' Journal of Business Ethics 44:95105.

Villagra, N. \& B. López (2013). 'Analysis of values and communication of the responsible brands. Corporate brand strategies for sustainability' in Communication \& Society 26(1):196-221.

Wagner, T.R., Lutz, R.J. \& B.A. Weitz (2009). "Corporate Hypocrisy: Overcoming the Threat of Inconsistent Corporate Social Responsibility Perceptions" in Journal of Marketing 37(2):170-180.

Weerd, H. D. (2001). 'Plezier in Werken. Zingevingsaspecten en warden op die Werkvloer', in Corporate Social Responsibility: Balancing Between Thinking and Acting, Cramer, C. Van der Heijden, A., and Jonker, J., ICCSR, No. 28-2004

Yoon, Y., Gürhan-Canli, Z. \& N. Schwarz (2006). 'The Effect of Corporate Social Responsibility (CSR) Activities on Companies with Bad Reputations' in Journal of Consumer Psychology 36(2):63-74.

Young, S. (2001). Keynote Speech - 2001 Caux Conference, Switzerland, 14 July 2001.

Zyglidopoulos, S.C. (2002). 'The social and environmental responsibilities of multinationals: evidence from the Brent Spar case' in Journal of Business Ethics 36(1-2):141-151. 
